\title{
Relationship of Iron Deficiency Anemia with Simple Febrile Seizure in Children
}

\author{
SGHOSAL
}

\begin{abstract}
Summary:
Background and objective: Febrile Seizure (FS) is the commonest seizure disorder among under 5 children. Iron deficiency is a documented risk factor of FS and as the data about the relationship of iron deficiency with FS among Bangladeshi children is scanty, this study was undertaken to assess the association of Serum Ferritin to simple FS.

Materials and Methods: This case control study was conducted at the department of pediatrics of SSMC \& Mitford Hospital during $7^{\text {th }}$ May 2011 to $6^{\text {th }}$ January 2012 on consecutive 120 children aged between five months to six years who fulfilled the inclusion criteria were considered as cases. Similar number of age and sex matched children admitted with fever without seizures were taken as controls. All candidates were gone through $C B C$ with $R B C$ indices and serum ferritin and iron deficiency anemia was diagnosed on the basis of mentioned tests.
\end{abstract}

Results: The results showed that majority of the cases were male (66.7\%) and most of them were between 13-24 months

Introduction:

Febrile Seizures (FS) are the commonest seizures in children and one of the most common cause of pediatric emergency, in $3-4 \%$ of children under the age of 5 years ${ }^{1}$.Global incidence of febrile seizure is $4.8 /$ 1000person/year ${ }^{2}$. The incidence is higher in developing countries because of their increased incidence of infection ${ }^{2}$. Owing to their association with epilepsy in future in some cases, various studies have attempted to identify the risk factors associated with FS like family history of FS or epilepsy, perinatal factors like maternal smoking \& alcohol consumption ${ }^{3}$. Among several other risk factors iron deficiency has been found as a provocating factor of FS in different studies ${ }^{4,5}$. In iron deficiency, there is deficiency of several neurotransmitters like monoamine oxidase, aldehyde oxidase that seems to be responsible for $\mathrm{FS}^{6}$. Studies

Address of Correspondence: Dr. Sharmistha Ghosal, Junior Consultant, Paediatrics, 250 Bedded General Hospital, Gopalgonj, Mobile: 01716868645, e-mail: sharmistha58@gmail.com

Received: 11 February 2016

Accepted: 2 March 2017 of age (51.7\%). Mean duration of convulsion was less than 5 minutes in $70 \%$ of the cases. Level of $\mathrm{Hb}$ was low in both the cases and controls but the other RBC indices for anemia like $\mathrm{MCV}, \mathrm{MCH}, \mathrm{MCHC}$ and serum ferritin were significantly lower among the febrile seizures group in comparison to controls. The chi-square test is indicated as a significant difference between two groups and odds ratio is 6.0 which signifies that febrile seizure group were 6.0 times more likely to develop iron deficiency anemia compared to control group.

Conclusion: The findings suggest that children with febrile seizure have association with iron deficiency anemia (which is evident by microcytic hypochromic anemia and low serum ferritin level).This means low serum ferritin and presence of anemia can serve as a risk factor for febrile seizure in children.

Key words: Fever, simple febrile seizure, iron deficiency anemia.

(J Bangladesh Coll Phys Surg 2017; 35: 75-79)

reported that Low level of serum ferritin may lower the seizure threshold ${ }^{5}$ and fever can worsen the negative effects of low serum ferritin on the brain and trigger seizure $^{4}$. Several studies were conducted in different parts of the world to see the risk factor of febrile seizure and found a relationship of iron deficiency anemia and febrile seizure. Still in Bangladesh no study was conducted to see the risk factors of FS. Through this study we can explore the relationship of FS and then programs pertaining to prevention of FS can be undertaken to lower the risk of recurrence of FS and its consequences.

Materials and Methods:

A case control study was conducted at pediatric department of SSMC \& Mitford Hospital over one year following approval by ethical review committee of same institution. Sixty consecutive children aged 5 months to 6 years admitted to pediatric ward with simple febrile seizure(Case definition: Simple febrile seizure is defined as a primary generalized, usually tonic-clonic, attack associated with fever, lasting for a maximum 15 minutes 
and not recurrent within a 24 hour period $^{7}$ ) were enrolled as cases (Age 5 mon-6years of both sexes, single generalized tonic colonic convulsion within $24-48$ hours of onset of fever, first and subsequent febrile seizure, no CNS manifestation, with or without positive family history). A reference group of 60 children of age and sex matched having febrile illness without seizures were selected as controls. Samples with age $<5$ months or $>6$ years, atypical febrile seizure, unconsciousness, electrolyte imbalance, having developmental anomaly, neurological deficit or with CNS manifestations were excluded from the study. Informed written consents were obtained from parents or care-givers after explaining the objective of this study. After thorough history and physical examination, the following investigations hemoglobin $(\mathrm{Hb})$, mean corpuscular volume (MCV), mean corpuscular hemoglobin $(\mathrm{MCH})$, and serum ferritin were done and the findings were recorded on a preset questionnaire. In this study iron deficiency anemia was defined as $\mathrm{Hb}<12 \mathrm{gm} / \mathrm{dl}, \mathrm{MCV}<80 \mathrm{fl}, \mathrm{MCH}<27 \mathrm{pg}$, $\mathrm{MCHC}<33 \mathrm{gm} / \mathrm{dl}$ and S. ferritin $<7 \mathrm{ng} / \mathrm{dl}$. S. Ferritin was estimated by CMIA (chemiluminescent microparticle immunoassay ). Then all collected data were recorded, compiled and were analyzed by SPSS 12 .

\section{Results:}

A reference group of 60 children of age and sex matched having febrile illness without seizures were selected as controls. The above table shows that majority of cases and controls were between 13 to 24 months age group and out of 60 cases $24(41.7 \%$ ) had family history of febrile seizure.

Table shows the severity of anemia among the cases and controls. Grading of anemia was moderate to severe in majority of cases $(60 \%)$ whereas that was mild among the controls (80\%). A significant number of cases had low serum ferritin level in comparison to controls and the mean difference of blood MCV $(\mathrm{p}<0.001), \mathrm{MCH}(\mathrm{p}$ $<0.001)$ and MCHC $(\mathrm{p}<0.001)$ which are statistically significant i.e. all the parameters (except $\mathrm{Hb}$ level) related to RBC indicating anemia were significantly lower among the cases in comparison to controls.

This table shows low serum ferritin has association with the occurrence of simple febrile seizure (odds ratio $1,95 \%$ CI 14.96-173.5). This table shows that the febrile seizures was 6 times vulnerable to develop in moderate to severe anaemia $(\mathrm{CI}=2.47-14.85)$. It also shows an association with serum ferritin level among cases and control. It has been found that cases having serum ferritin

Table-I

\begin{tabular}{|c|c|c|c|c|c|}
\hline \multicolumn{6}{|c|}{ Demographic characteristics } \\
\hline \multirow[t]{2}{*}{$\begin{array}{l}\text { Demographic } \\
\text { characteristics }\end{array}$} & \multicolumn{2}{|c|}{$\begin{array}{c}\text { Cases } \\
(\mathrm{No}=60)\end{array}$} & \multicolumn{2}{|c|}{$\begin{array}{l}\text { Controls } \\
(\mathrm{No}=60)\end{array}$} & \multirow[t]{2}{*}{$P$ value } \\
\hline & No & $\%$ & No & $\%$ & \\
\hline \multicolumn{6}{|l|}{ Age (in months) } \\
\hline$<12$ & 24 & 40.0 & 23 & 38.3 & $0.07^{\mathrm{ns}}$ \\
\hline $13-24$ & 31 & 51.7 & 24 & 40.0 & \\
\hline$>25$ & 5 & 8.3 & 13 & 21.7 & \\
\hline \multicolumn{6}{|l|}{ Sex } \\
\hline Male & 40 & 66.67 & 38 & 63.33 & $0.7^{\mathrm{ns}}$ \\
\hline Female & 20 & 33.33 & 22 & 35.67 & \\
\hline \multicolumn{6}{|c|}{ Family history of febrile seizure } \\
\hline Yes & 25 & 41.7 & & & \\
\hline $\mathrm{Sib}$ & 4 & 6.7 & & & \\
\hline Parents & 10 & 16.7 & & & \\
\hline Others & 11 & 18.3 & & & \\
\hline Non & 35 & 58.3 & & & \\
\hline
\end{tabular}

$\mathrm{ns}=$ Not significant; $\mathrm{P}$ value reached from unpaired t-test 
Table-II

\begin{tabular}{lccc}
\multicolumn{4}{c}{ Clinical profile and investigation results } \\
Anaemia & Cases No (\%) & Controls No (\%) & P value \\
\hline Present & $56(93.3)$ & $59(98.3)$ & $0.17^{\mathrm{NS}}$ \\
Absent & $4(6.7)$ & $1(1.7)$ & \\
Severity of anemia & & \\
Severe (3-6 gm/dl) & $07(11.7)$ & 01 & $<0.001^{\mathrm{S}}$ \\
Moderate (6-9 gm/dl) & $29(48.3)$ & $12(20.0)$ & \\
Mild (9-12 gm/dl) & $24(40.0)$ & $47(80.0)$ & \\
Investigation & & & \\
Hb (g/dl) & $10.32 \pm 8.7$ & $9.92 \pm 1.18$ & $0.72^{\mathrm{NS}}$ \\
MCV (fl) & $69.39 \pm 5.90$ & $77.38 \pm 3.70$ & $<0.001^{\mathrm{S}}$ \\
MCH (pg) & $23.74 \pm 2.65$ & $29.0 \pm 2.49$ & $<0.001^{\mathrm{S}}$ \\
MCHC (gm/dl) & $28.69 \pm 3.66$ & $31.35 \pm 3.41$ & $<0.001^{\mathrm{S}}$ \\
Serum Ferritin(ng/ml) & & & \\
$<7$ & $52(86.7 \%)$ & $7(11.7 \%)$ & $<0.001^{\mathrm{S}}$ \\
$>7$ & $8(13.3 \%)$ & $53(83.3 \%)$ & \\
\hline
\end{tabular}

$\mathrm{NS}=$ nonsignificant, $\mathrm{s}=$ significant; $\mathrm{P}$ value reached from chi-square test

Table-III

Association of and anemia and serum ferritin between febrile seizure and fever without seizure $(n=120)$

\begin{tabular}{lccccc} 
Determinants & $\begin{array}{c}\text { Febrile } \\
\text { seizure }\end{array}$ & $\begin{array}{c}\text { Fever without } \\
\text { seizure }\end{array}$ & $\begin{array}{c}\text { Odds } \\
\text { ratio }\end{array}$ & $95 \% \mathrm{CI}$ & P value \\
\hline Anemia & 36 & 12 & 6.00 & $2.47-14.85$ & $<0.001^{\mathrm{s}}$ \\
$\begin{array}{l}\text { Moderate to severe } \\
\text { Mild }\end{array}$ & 24 & 48 & & & \\
Serum ferritin & & & 49.21 & $14.96-173.5$ & \\
$<7 \mathrm{ng} / \mathrm{ml}$ & 52 & 7 & & & $<0.001^{\mathrm{s}}$ \\
$>7 \mathrm{ng} / \mathrm{ml}$ & 8 & 53 & & & \\
\hline
\end{tabular}

$\mathrm{S}$ = significant; $\mathrm{P}$ value reached from chi-square test

level $<7 \mathrm{ng} / \mathrm{ml}$ has 49 times more chance of having febrile seizure than control $(\mathrm{CI}=14.96-173.5)$.

\section{Discussion:}

This hospital based case- control study was carried out to see the iron status of under 5children with febrile seizure children aged 5 to 60 months taking age and sex matched non febrile seizure peers as control.

The relevant findings of this study were discussed and compared with those of previously and recent published studies.
In our study the mean haemoglobin concentration of the cases and that of controls were low and the difference was nonsignificant (p-0.72). Vaswani et al ${ }^{6}$ showed both cases \& controls group had anemia (defined by $\mathrm{Hb}$ less than $11 \mathrm{gm} / \mathrm{dl}$ ) but did not mentioned the severity of anemia in both groups. Daoud et $\mathrm{al}^{8}$ also showed low $\mathrm{Hb}$ level in both groups but proportion were higher among cases.

In the present study the mean $\mathrm{MCH}, \mathrm{MCHC}, \mathrm{MCV}$ and serum ferritin $(\mathrm{ng} / \mathrm{ml})$ were significantly $(\mathrm{p}<0.05)$ less in children having febrile seizure than those in controls. 
Daoud et $\mathrm{al}^{8}$ mentioned that $\mathrm{Hb}, \mathrm{MCV}$ and $\mathrm{MCH}$ levels were also lower in the cases than controls. However, the differences were not statistically significant in their study. Hartfield et $\mathrm{al}^{9}$ found the Hb level was almost similar between two groups, $\mathrm{MCH}$ was significantly low in case group. Modaresi ${ }^{10}$ et al, Gancer et al ${ }^{11}$ and Mall et $\mathrm{al}^{12}$ also noticed the mean $\mathrm{Hb}, \mathrm{HCT}, \mathrm{MCH}$, serum iron level significantly lower in case group than in control group.

In this study majority cases had low serum ferritin level ( $<7 \mathrm{ng} / \mathrm{ml}$ ) comprising $86.7 \%$ on the other hand, in control group serum ferritin level $>7 \mathrm{ng} / \mathrm{ml}$ in the most of children $(88.3 \%)$. So, the difference is statistically significant i.e significant number of the cases had low serum ferritin level in comparison to controls. Daoud et al. ${ }^{8}$ mentioned that mean ferritin level were lower in children who had a seizure with fever, suggesting a possible risk factors in febrile seizures. They have shown that the mean plasma ferritin level was significantly lower $(p<0.0001)$ in the first febrile seizure group compared to the reference group. Vaswani et al. ${ }^{6}$ observed significantly low serum ferritin value in case than that of control. However Yousefichaijan et $\mathrm{al}^{13}$

observed that only $22.5 \%$ child with febrile seizure had iron deficiency anaemia and $34 \%$ of control group exhibit anaemia $(p<0.001)$.Febrile seizure group had significantly high $\mathrm{RBC}$ indices(MCV,MCH,MCHC) compared to control group.

In this current study we found low serum ferritin has association with the occurrence of simple febrile seizure (odds ratio 1;95\%CI 14.96-173.5). Saeed et al ${ }^{14}$ showed positive association of Iron Deficiency Anemia with febrile seizure. In their study mean serum ferritin level in case $6.9 \mu \mathrm{g} / \mathrm{L} \&$ in control $7.9 \mu \mathrm{g} / \mathrm{L}$. Nasehi et al ${ }^{15}$ observed odds ratio of Iron Deficiency Anaemia in children with febrile seizure in comparison to the control group was 1.27(CI 95\%-1.03-1.56). Here ferritin level was not significant between the two groups $(p=0.08)$ but the iron level in two groups was significant $(p=0.00)$. Habibian $^{16}$ et al, Ghasemi ${ }^{17}$ et al and Srinivasa ${ }^{18}$ et al also found odds ratio $1.52,1.89$ and 1.84 respectively for iron deficiency anemia in patient with febrile seizure compared to febrile children without seizure. The main limitation was the potential confounding effect of serum ferritin as an acute phase reactant which can interfere with the influence of iron status on febrile seizures. This limitation could be overcome by predicting the time when serum ferritin level returned to its baseline value after acute phase reaction and by estimation of Total Iron Binding Capacity.

\section{Conclusion:}

It is concluded that the febrile seizures are associated with low $\mathrm{MCH}$ and serum ferritin level. To ascertain the significance of this finding and its role in the development of febrile seizures large and multicenter studies are required.

\section{References:}

1. Singhi P. Seizures and Epilepsy in Children- A Practical Guide. New Delhi: Hira SK: 2008.

2. Salehi OM, Tamaddoni A, Nasehi MM, Badazadeh H, A lizadeh NR. Iron status in febrile seizures: a case control study. Iran J Child-Neurology 2009; 41: 39-41.

3. Daoud AS, Batieha A, Abu-Ekteish F, Gharaibeh N, Ajlouni S, Hijazi S. Iron Status: A Possible Risk Factor for the First Febrile Seizure. Epilepsia 2002; 43: 740-43.

4. Pisacane A, Sansone R, Impaglizzo N, Coppola A, Rolando P, D' Apuzzo A et al. Iron deficiency anaemia and febrile convulsion: case control study in children under 2 yrs. BMJ 1996, 313: 343-45.

5. Oski FA, Honig AS. The effects of therapy on the developmental scores of iron deficient infants. Pediatrics 1978; 92: 21-25

6. Vaswani RK, Dharaskar PG, Kulkarni S, Ghosh K. Iron Deficiency as a Risk Factor for First Febrile Seizure. Indian Paediatrics 2010; 47: 437-39.

7. Mikati MA, Febrile seizure. In: Kliegman RM, Behrman RE, Jenson HB, Shanton BF, editors. Nelson Textbook of Paediatrics. $19^{\text {th }}$ editon, Philadelphia:WB Saundars; 2011: p.2019-20

8. Daoud AS, Batieha A, Abu-Ekteish F, Gharaibeh N, Ajlouni S, Hijazi S. Iron Status. A Possible Risk Factor for the First Febrile Seizure. Epilepsia 2002; 43: 740-43.

9. Hartfield DS, Tan J,Yager YJ,Rosychuk MR, Spady $\mathrm{D}$, Haines $\mathrm{MC}$ et al. The association between iron deficiency and febrile seizures in childhood.2009; 48: 420426.

10. Modaresi M, Mahmodian T,Yaghini O,Kelishadi R,Golestani H,Tavasoli A et al.Is Iron Insufficiency Associated With Febrile Seizure?Experience in Iranian Hospital.J Comprehen Ped 2012,3(1):21-24.

11. Gancer H, Kafadar I, Kose G,Yildirmark Y.Relatoinship of Febrile Convulsion with Iron Deficiency Anemia and Zinc Deficiency.JAREM 2016;6:94-7.

12. Malla T, Mall K K, Sathian B,Chettri P,Sing S, Ghimire A. Simple Febrile Convulsion and Iron Deficiency Anemia:A Corelation in Nepalese Children.American Journal of Public Health Research.Vol-3,No.5A.2015,p11-16. 
13. Yousefichaijan P, Zolfi M, Firouzifar M. The relationship between iron deficiency anemia and simple febrile convulsion in children.J Pediatr Neurosci,2014,vol-9(2),p$10-14$.

14. Saeed T,Huq MZ,Kanwal A,Zulfiqur R,Raja TM.Association of Iron Deficiency Anaemia and Febrile Seizure in children.JRMC2013,17(2):175-7.

15. Nasehi MM,Abbaskhanian A,Omran MRS.Association between Iron Defficiency Anaemia and Febrile Seizure :A Systemic Review \& Meta-Analysis.J Pediatr Rev 2013;1(2) :13-18.
16. Habibian N, Alipour M A,Rezaianzedah A. Association between Iron Deficiency Anemia and Febrile Convulsion in 3-60 Month Old Children.A systemic review and Metaanalysis.Iran J Med Sci.2014Nov;39(6):496-505.

17. Ghasemi F,Valizadeh F,Taee N.Iron deficiency Anemia in Children with Febrile Seizure:A case-control studyIran J Child Neurol.2014Spring;8(2):38-44.

18. Srinivasa S,Reddy S P.Iron deficiency anemia in children with simple febrile sseizures-A cohort study.Curr Pediatr Res 2014; vol 18(2):95-98. 